\title{
Robust-yet-fragile nature of partly engineered social-ecological systems: a case study of coastal Bangladesh
}

\author{
Asif Ishtiaque $^{1}$ Nikhil Sangwan $^{2}$ and David J. Yu ${ }^{2,3,4}$
}

\begin{abstract}
Modern social-ecological systems are often partly engineered to enhance the robustness (or reduce the variance) of human welfare to environmental fluctuations over a foreseeable time horizon. Recent studies show, however, that subtle trade-offs are usually inherent in such efforts of enhancing short-term robustness. Managing variance on short time scales is likely to be associated with the buildup of hidden fragilities on longer time scales. Using a flood-prone social-ecological system (SES) of coastal Bangladesh as an example, this paper investigates some of the ways in which such robustness-fragility trade-offs can manifest. This SES has been extensively modified in the last few decades through the construction of large-scale flood protection structures (polders) and the introduction of commercial shrimp farming to enhance the robustness of food production to hydrological variability. Our case study analysis of the long-term changes in the SES shows that, although the modifications helped with stability in short time scales, the resulting changes also induced unforeseen problems such as infrastructure maintenance issues, land degradation and sinking, and exposure to market volatility. With this paper therefore we contribute to better understanding of the notion of robustness-fragility trade-offs by illustrating an exemplary case of the phenomenon in the engineered coastal environment context.
\end{abstract}

Key Words: coastal resilience; coastal vulnerability; cyclone; embankments; flooding; infrastructure; land subsidence; polder; robustness; robustness-fragility trade-offs; saline water intrusion; social-ecological systems; socio-hydrology; storm

\section{INTRODUCTION}

The emergence of a partly engineered coastal environment and semi-intensive aquaculture for export has reconfigured the socialecological system (SES) in southwest Bangladesh (SWBD). For centuries, the local people produced food for subsistence in the highly variable and sparsely populated environment of the Ganges-Brahmaputra river delta, practicing small-scale agriculture and aquaculture in the tidal floodplains. Large tracts of low elevated lands in these floodplains are naturally flooded twice a day. In the 1960s and 1970s, however, the region witnessed the construction of coastal embankments (polders) that are designed to control the variable environment. A polder is a tract of floodplain enclosed by dykes or embankments that prevent flooding (Fig. 1B and C). Since their completion, the polders have helped to reduce the variance of human welfare to environmental fluctuations by containing the normal ranges of flooding. Intensified crop cultivation and commercial shrimp farming (CSF) became possible as a result (Saari and Rahman 2003, Ahmed et al. 2008).

The stability created by the polders has dramatically altered the context in which the SES operates. More complex humanenvironment interactions have developed on the floodplains because of the increased population and economic activities and the requirement of maintaining the larger scale infrastructure. The SES has also become more tightly coupled to the greater, outside system through CSF, i.e., producing local marine resources for the global market (Islam 2006). With the accelerating globalization, the flow of people and goods between the polders and urban areas has intensified in the recent years. This dynamic interplay between social, infrastructural, and hydrological processes makes the system one of the most interesting cases for studying the robustness of engineered SESs in the coastal environment context. This leads us to ask the following questions: How have these changes affected the robustness of the SES in the long run? Has the management of SES variance through the polders and CSF amplified fragilities in longer time scales? If so, how have these fragilities developed over time? We tackle these questions by conducting a long-term case study analysis of the coastal SES in SWBD.

We use the systems perspective of robustness to understand the effects of the variance management. Robustness, a concept that originated in engineering, relates to the sensitivity of a system output to a well-defined set of known disturbances (Csete and Doyle 2002). In contrast to resilience, which tends to focus on the capacity of self-organized systems to deal with various kinds of disturbances, robustness focuses on how engineered systems maintain a specific system output when subjected to a much narrower set of known disturbances (Anderies et al. 2013). The term robustness is being increasingly used to study SESs in which the role of engineered components is explicitly present, such as irrigated agricultural systems (Cifdaloz et al. 2010), flood protection systems (Mens et al. 2011, Daupras et al. 2015), urban recreational fisheries (Krupa et al. 2014), and geoengineering (Bahn et al. 2015). Robustness fits well with the current study because the focal SES has been engineered to control the variable environment over a foreseeable time horizon.

Applying the robustness perspective typically requires, at minimum, clear definitions of what is included in the system boundary and what is the system output of interest for which robustness is considered. We define the boundary of our focal SES to include the following components: tidal plains of SWBD, the villages in the region that engage in aquaculture, agriculture, or both, and the polder infrastructure and CSF for export. The system output of interest is the food security, and protection of the people in the SES from hydro-meteorological disasters.

${ }^{1}$ School of Geographical Sciences \& Urban Planning, Arizona State university, Tempe, AZ, USA, ${ }^{2}$ Lyles School of Civil Engineering, Purdue University, West Lafayette, IN, USA, ${ }^{3}$ Department of Political Science, Purdue University, West Lafayette, IN, USA, ${ }^{4}$ Center for the Environment, Purdue University, West Lafayette, IN, USA 
Fig. 1. (A) Map of the study area. The numbers shown in the colored areas of the magnified map represent the polder identification numbers (numbered 1 through 37). (B) A crosssectional diagram of a standard polder system. The polder concept came from the Netherlands to protect low-lying areas from sea water. A polder is comprises three components: embankments, sluice gates, and canals. Embankments protect the polder area from flooding. Sluice gates and canals are used to convey water into and out of a polder. (C) A diagram of a typical standard polder system in southwest Bangladesh where agricultural lands and shrimp ponds coexist. Agricultural farmers mainly use deep tube wells to irrigate fields whereas shrimp farmers trap saline water from the river through sluice gates. During winter when river water becomes more saline, farmers use river water or captured rainwater to dilute salinity. In the nonirrigated areas, agriculture farmers rely on rain water for farming.

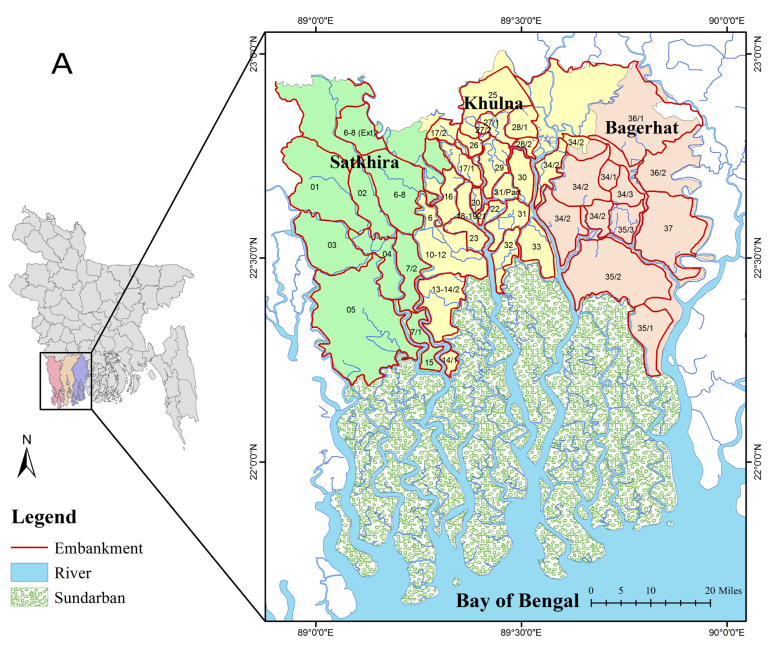

B
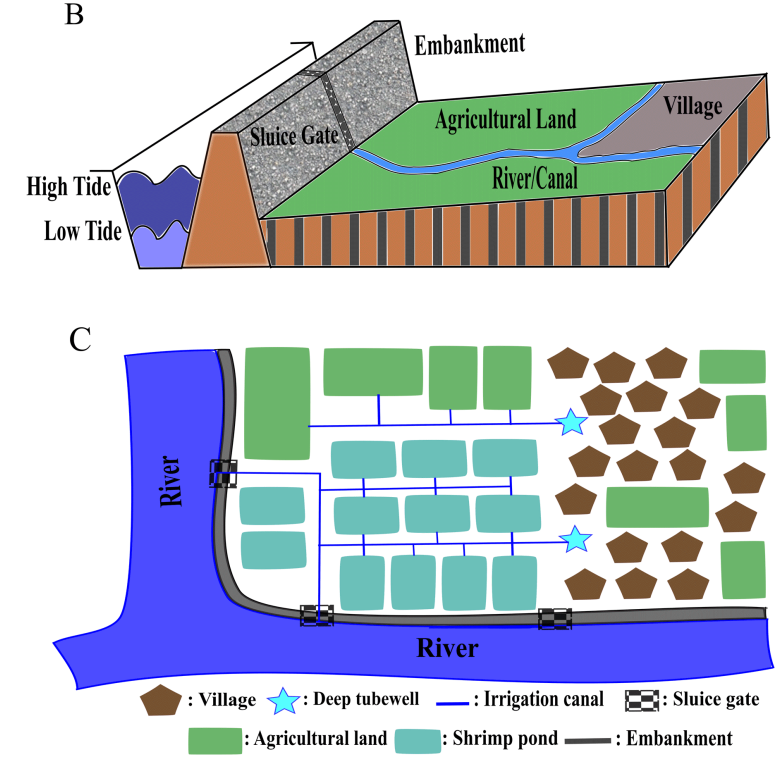

Robustness perspective provides an important insight on tradeoffs associated with managing variance in short time scales and the buildup of fragilities in different spatiotemporal scales, i.e., robustness-fragility trade-offs (Carlson and Doyle 2002). The notion of robustness-fragility trade-offs (RFTOs) stipulates that, by becoming robust or insensitive to a particular set of disturbances, systems necessarily become fragile or sensitive to disturbances outside that set. The study, for example, on Hohokam of Phoenix basin showed that the development of public infrastructures to augment the productivity of irrigated agriculture ensured robustness to short-term environmental fluctuations in rainfall, yet the system became fragile to infrequent large floods (Anderies 2006). Such RFTOs are dangerous because emergent fragilities are usually hidden and are only revealed through failures. Resilience theorists have recently shown that such RFTOs may be a general phenomenon across different types of SESs (Carpenter et al. 2015) and that a typology can be developed to classify commonly occurring RFTOs (Anderies 2015). According to this typology, two types of RFTOs may be particularly relevant to the current study: structural RFTO and network RFTO. Structural RFTO represents a direct modification to the system structure, e.g., the construction of polders, that stabilizes a desired system output, but which is also likely to be associated with increased sensitivity in some other dimension. For example, the construction of Farakka barrage to divert water for irrigation in upstream India caused salt-water intrusion in coastal Bangladesh (Gain and Giupponi 2014). Network RFTO, on the other hand, represents an insertion of an exchange network that stabilizes a system output but which might also amplify fragilities because of the connection to the larger network. In northeast Brazil, to illustrate, a crop insurance program increased the robustness of the farming system by compensating the natural disturbance induced production damages (Lemos et al. 2016), and thus the system was made more sensitive to national and global economic fluctuations. Building on these insights, we analyze RFTOs that have occurred in the study system.

In the literature, numerous studies have investigated various social or ecological aspects of coastal Bangladesh in a different light. For example, several studies investigated some aspects of livelihood issues, such as collective management of shared water resources (Afroz et al. 2016), flood protection and rural-urban migration (Choudhury et al. 2004, Di Baldassarre et al. 2015), climate change impacts on agriculture (Huq et al. 2015, Lázár et al. 2015), and the rise of more intensive forms of aquaculture (Swapan and Gavin 2011). These studies tend to center on household-level vulnerabilities and responses to cope with emerging challenges. In another set of studies, scholars focused on ecological consequences of modifying the landscape. For example, Auerbach et al. (2015) and Temmerman and Kirwan (2015) examined interruptions to natural sedimentation processes and the rising sea-land level differences after the construction of the embankments. Several studies also examined environmental issues such as rising soil salinity (Rahman et al. 2000, Ali 2006) and the integrity of Sundarbans mangrove ecosystem (Gopal and Chauhan 2006). We build on and complement the existing studies by applying the lens of robustness and RFTOs to understand how system-level fragilities have shifted over time. We used literature survey and field interviews to collect the data necessary for this longitudinal analysis. 


\section{The study area}

The study area, comprising Satkhira, Khulna, and Bagerhat districts, is located at the Ganges-Brahmaputra delta in southwest Bangladesh (Fig. 1A). A complex social-ecological system has been created here by the following: (1) vast stretches of floodplains that are enclosed by embankments; (2) presence of agriculture and shrimp farming; and (3) ecologies of the GangesBrahmaputra river delta that includes the Sundarbans, the largest single patch mangrove forest in the World. Even before the construction of the polders, the Sundarbans has functioned as the front line of defense against natural hazards by suppressing the impact of cyclones and storm surge. The Sundarbans has also been an important source of livelihood for the local residents, providing resources such as firewood, honey, and crabs (Aziz and Paul 2015).

Through the support of the Bangladesh government and multilateral donor agencies, most of the coastal lines in the area were embanked to create polders in the 1960s and 1970s. In total, 37 polders comprising $1556 \mathrm{~km}$ of embankments and 282 sluice gates were constructed in our study area to better protect the floodplains from tidal surge and saline water intrusion. The construction of the polders enabled agriculture and shrimp farming to flourish in the region. Typically, produced crops are rice, vegetables, and lentils. Farmers usually use groundwater or capture and store rainwater to irrigate their fields. In addition, during the monsoon season when the river water is less saline, farmers use river water and captured rainwater to flush out salts in the soil to reduce soil salinity (Afroz et al. 2016).

About $80 \%$ of shrimp farms in Bangladesh are located in the SWBD (Alam et al. 2005, Pokrant 2006). Shrimp farms are usually situated near the river channels or canals, which facilitates them to regularly recharge shrimp pond water. Two types of shrimps are predominantly produced: black tiger shrimp (Penaeus monodon), referred to as bagda among locals, and giant freshwater shrimp (Macrobrachium rosenbergii), referred to as golda among locals (Rahman and Hossain 2009). The bagda shrimp farmers use saline water to produce shrimp, while the golda shrimp farmers utilize fresh water. During the dry season, when the pond water dries up, golda farmers cultivate crops in their desiccated ponds. Bagda farmers rest their ponds in winter season for maintenance or to cultivate salt (Ali 2006). Shrimp farmers in our study area predominantly culture bagda shrimp. These farmers use sluice gates and canals to distribute saline water during high tides.

\section{Research framework and data source}

We use the robustness framework (Anderies et al. 2004) to analyze the dynamics of our focal SES over time (Fig. 2). The framework delineates four generic components of a SES (resource, resource users, public infrastructure, and public infrastructure providers), their interrelationships, and how these components and interrelationships influence the capacity of a SES to withstand internal or external disturbances. Unlike other SES frameworks, it explicitly recognizes the role of public infrastructure. Public infrastructure can be either "hard," e.g., dams and embankments, or "soft," e.g., formal and informal institutions, structures, and is typically designed and maintained to reduce the variance of a system output. These features make the framework a useful tool for studying SESs that are partly engineered to be robust against a particular set of disturbances.
Fig. 2. The conceptual model of the robustness framework adapted from Anderies et al. (2004). It specifies four generic components common to most social-ecological systems (resource, resource users, public infrastructure, and public infrastructure providers) and their interrelationships (links 1 to 6). It also explicitly describes the presence of disturbances (links 7 and 8).

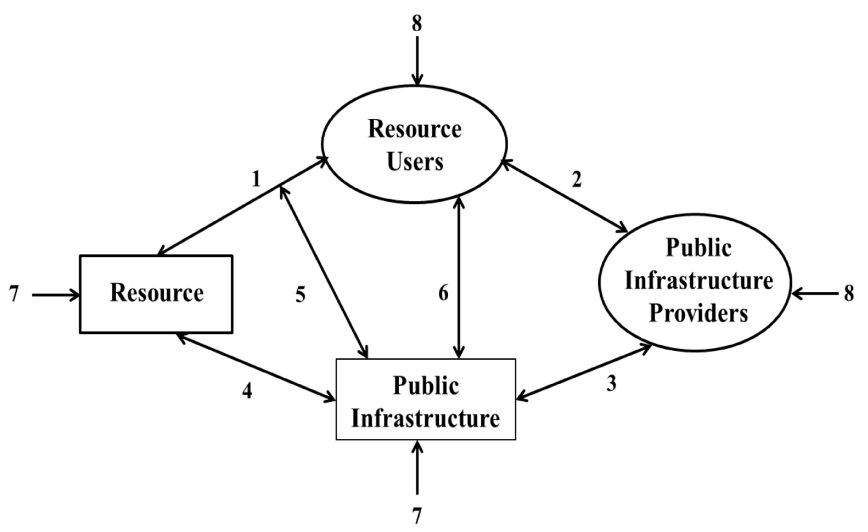

The interrelationships among the four components can be outlined as the following. Users derive benefit flows from a resource system (link 1 in Fig. 2), but users might not interact directly with the resource system in certain cases. In those instances they interact through some public infrastructures. These public infrastructures can be hard infrastructures such as dams and canals that reduce variance in benefit flows (link 4). The farmers of Caravaca aquifer in Spain, for instance, used to extract groundwater using traditional methods; however, because of population growth and commercialization of agriculture new farmers started to extract groundwater using regional government provided public infrastructures such as wells or reservoirs (Pérez et al. 2011). Notably, these public infrastructures can also be soft infrastructures such as institutional arrangements that reduce unpredictability in human interactions with the environment (link 5). To obtain these benefits, users often coproduce or participate in the maintenance of public infrastructure (link 6). However, not all users get involved in maintaining the public infrastructure. There may be a separate entity, a government agency for example, that builds and maintains public infrastructures for the users (link 2 and 3). This entity is referred to as public infrastructure providers. Finally, socioeconomic disturbances can disrupt the activities of the users and the public infrastructure providers (arrow 8). Natural disturbances such as floods and cyclones can also impact the functioning of the resource system and the public infrastructure (arrow 7).

We conducted a literature survey and key-informant interviews to collect information for our case study analysis. Several journal articles and reports on the region's livelihood vulnerability issues were analyzed. This effort was followed by interviews with 23 local residents in the area, 10 of which were shrimp farmers, (12 farmers are from Satkhira, 7 from Khulna, and 4 from Bagerhat). The interviewees were selected on the ground that they possessed sufficient knowledge and experience to comment about the past 
and the present status of the study area. The format of the interviews was open ended. Key issues were identified through detailed conversations. Frequently discussed topics included exposure to natural hazards, social conflicts and their resolution, management of water resources, and availability of government support and aids during emergency situations.

\section{ROBUSTNESS ANALYSES}

We used the lens of robustness to trace the system-level changes of the SES over time. Our analysis proceeded through three stages. First, we examined the robustness and fragility of the system prior to the construction of the polders, i.e., the traditional system. Next, we traced how the system robustness was altered after the construction of the polders or Coastal Embankment Project (CEP). This was followed by another robustness analysis that explored the effects of commercial shrimp farming (CSF).

\section{Analysis I: The traditional system}

Until the late 18th century, the coastal areas of Satkhira, Khulna, and Bagerhat were covered with dense forests with most people living in the periphery. These peoples' livelihood activities were limited to harvesting forest resources (timber, fruits, honey), fishing, and small-scale agriculture. Agriculture was not easy because high tides inundated a large tract of area twice a day. This area is also susceptible to tropical cyclones because of its low elevation from mean sea level and proximity to the Bay of Bengal.

The onset of British colonization in 1747 spurred encroachments to the forest lands. This happened because the colonial government sought to increase tax revenues by converting the forest lands into agricultural lands. The Zamindars (Indian landlords) took advantage of this policy by clearing large tracts of the forest lands and annexing them into their estates (Bandyopadhyay 2000). As a result, the forest lands in the area shrunk by $20 \%$ between 1873 and 1933 (Curtis 1933, Blasco 1977). The colonial government responded by declaring the forest lands as Khash Mohol (state-owned lands) and formulating forest policies and acts to reduce the encroachment (Das and Siddiqui 1985, Naskar and Mandal 1999).

Despite these measures, agricultural lands still gradually expanded in the area because parts of the state-owned forest lands were often leased out to Zamindars and other affluent people. These lands were further subleased out to peasants in exchange of regular payments of cultivated crops. To grow crops, the local people constructed small pockets of embankments (local name: berry bandh) with the assistance from Zamindars to reduce flooding (Bandyopadhyay 2000). In addition to agriculture, the local people also practiced aquaculture using the traditional method of cultivating fish (shrimp and white fin fish) in tidal waters trapped in shallow ponds (Ahmed et al. 2008, Rahman and Hossain 2009). This joint practice of agriculture and aquaculture helped to create more reliable food supply.

Based on the historical accounts given above, we analyzed the traditional SES using the robustness framework (Fig. 3). Resources are various forest resources (timber, honey, fruits, etc.), aquatic resources (shrimp, white fin fish), and soil fertility for growing crop. Users are the local people residing in the area. Public infrastructure comprises the Sundarbans (natural infrastructure for softening storm surge), earthen embankments ("hard" infrastructure), and the forest policies and acts ("soft" infrastructure). Zamindars and the colonial government are public infrastructure providers because they facilitated the creation of small-scale embankments and forest policies and acts, respectively.

Fig. 3. Application of the robustness framework to the traditional social-ecological system. Line thickness represents the relative importance of a given interaction or shock. The management of variance was limited in the traditional system. Although the components of public infrastructure (small earthen embankments, the Sundarbans, and forest policies and acts) helped with stability to some degree, the system was still fragile to natural disturbances and forest encroachment.

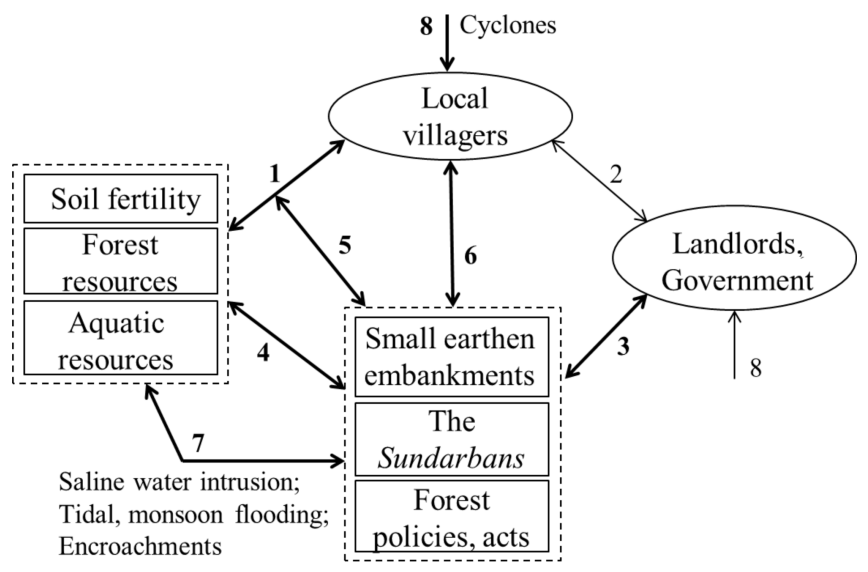

The local people harvested multiple resources. They extracted nutrients in the soil to produce crop, harvested fish and shrimp, and collected forest resources from the Sundarbans (arrow 1, Fig. 3). Harvesting of the resources in the low-lying grounds was aided by the small-scale earthen embankments (arrow 4), which were maintained by the local people (arrow 6) under the support of Zamindars (arrow 3; Bandyopadhyay 2000). The forest policies and acts introduced by the colonial government (arrow 3 ) helped to protect forest resources by controlling user behavior (arrow 5). The link between users and public infrastructure providers (arrow 2) was weak because ordinary farmers (resource users) were not actively involved in the decision making. Multiple disturbances affected the resources, public infrastructure, and users (arrows 7 and 8). Saline water intrusion during high tides threatened the soil fertility and the level of crop production, the encroachment and overharvesting menaced the stock and quality of forest resources, and the human settlements in the area were fragile to natural disasters such as tropical cyclones.

Overall, the management of variance was limited in the traditional system. Although the Sundarbans and the small earthen embankments suppressed the effects of cyclones and tidal inundation to some degree, they could not avert the flood or major cyclonic storm impacts because of low height. Thus, the local people and resources were still regularly exposed to flooding and saline water intrusion (Saari and Rahman 2003, Islam and Kibria 2006). As a result, agriculture was limited in the traditional system. People relied on small-scale agriculture and aquaculture and forest resources for subsistence. 


\section{Analysis II: Coastal Embankment Project (CEP)}

Hydro-climatic extremes periodically arise in the region (Khalil 1992). The traditional system was still largely vulnerable to these events because it did not have sufficient flood protection infrastructure. The new independent state of Bangladesh (then East Pakistan) finally took actions to address the issue by implementing the Coastal Embankment Project (CEP) in the 1960s and 1970s. Inspired by the Dutch model of polders and with the support of multilateral development agencies, this project involved construction of embankments along the river channels to enclose low-lying tracts of land of coastal areas. When the project was completed, the traditional system was turned into a partly engineered SES that is robust to normal ranges of flooding. In total, 37 polders, 282 sluice gates, and $1556 \mathrm{~km}$ of embankments were constructed in the region.

As envisioned, the polders improved the capacity of the SES to resist tidal flooding ( 5 to 6 feet high) as well as saline water intrusion (arrow 7, Fig. 4). Agriculture expanded in the area and crop production increased by two- to threefold, subsequently (arrow 4; Saari and Rahman 2003). More intensive forms of aquaculture also became viable because shrimp ponds in the lowlying grounds became less susceptible to being swept away by tidal surge (arrow 4). Overall, the level of poverty declined in the area after the completion of CEP (Tutu 2005). Furthermore, local water management organizations often constructed pumps and canals in the polders, where groundwater salinity is relatively low, to supply fresh water (ground water) for irrigation (arrow 6). The groundwater in the polders adjacent to the Sundarbans contained relatively high salinity, yet with the introduction of the CEP the temporary cropping became more intensified (Arfanuzzaman et al. 2016). Empirical evidence reports that social conflicts associated with using and maintaining the canals are rare in the region (arrow 6; Tutu 2005, Islam and Kibria 2006).

The polders did help to reduce the impact intensity of tropical cyclones, lowering the death toll to as low as five in the 1975 cyclone or 175 in the 1969 cyclone (arrow 8; Khalil 1992). Yet, the infrastructure was still limited in its capacity to buffer even low category cyclonic storms, such as the 1974 cyclone that made landfall through SWBD and claimed 600 human lives. Furthermore, the impact of the category-4 Great Bhola Cyclone in 1970, which claimed more than 300,000 human lives throughout Bangladesh, was also felt in SWBD (Murty et al. 1986, Van Schendel 2009). Although the CEP did make the SES robust to normal flooding, the system as a whole was still fragile to extreme events such as cyclonic storms. However, note that the damage depends not only on the intensity of the event. Diverse factors, such as, institutional capacity, adaptation mechanisms, poverty, can influence the outcomes. Because of the presence of increased agricultural output inside the polders, the SES has become more sensitive to low-probability events such as higher category cyclones compared to before. Further, the Great Bhola Cyclone of 1970 exposed a new source of system fragility: insufficient or deferred government support on disaster recovery. This delay in action (arrow 2) made the local people unprepared for another extreme event that might occur in quick succession. Indeed, another category-1 cyclone hit the SES in the following year. This successive disaster was likely to be associated with increased vulnerability because of lack of recovery from the Bhola cyclone. The inadequate preparation of local people coupled with lack of disaster recovery and external support made the outcome devastating: as many as 11,000 people died because of the repeated cyclone (Murty and El-Sabh 1992).

Fig. 4. The robustness diagram of the social-ecological system after the completion of the Coastal Embankment Project. Line thickness indicates the relative importance of a given interaction. The addition of polders made the system more productive in agriculture and robust to normal flooding and lower category cyclones. But the system became fragile to different challenges such as infrastructure maintenance issues, embankment failures from land subsidence, and various issues caused by siltation along the outer walls of embankments. The system also remained fragile to higher category cyclones.

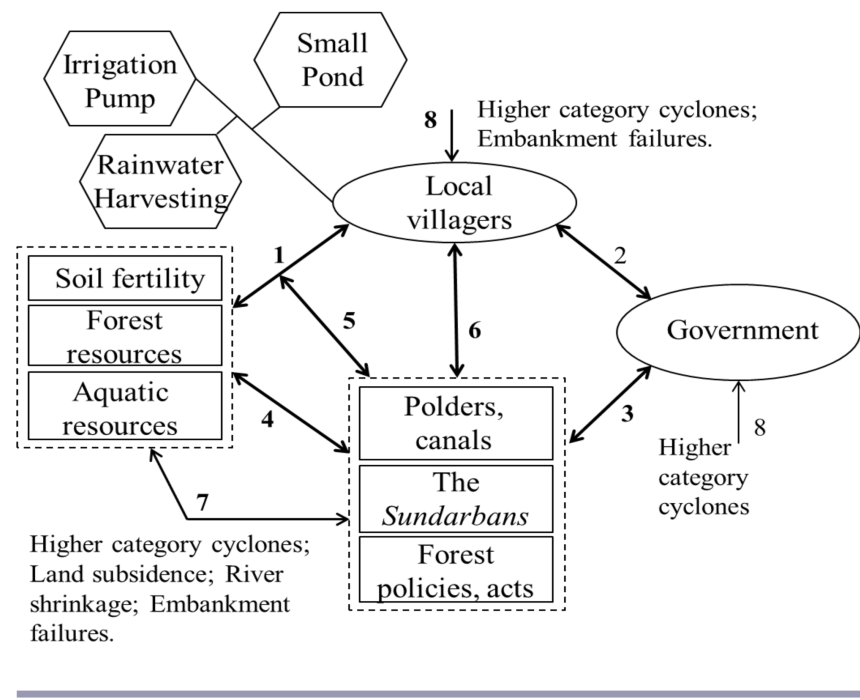

More crucially, the greater maintenance requirement associated with larger scale infrastructure made the SES fragile to infrastructure maintenance issues (arrow 6). To be operational, the polder infrastructure needs to be maintained periodically to deal with natural erosion (e.g., sluice gate malfunction, accumulation of debris in canals, and erosion of embankment height) and emergency events (e.g., embankment breach caused by storm surge). Empirical studies report that the polder infrastructure has been poorly maintained and has become dilapidated over the years (Paul 2009, Hossain 2015). This is in part due to insufficient government support in the maintenance works (arrows 2 and 3; Dewan et al. 2015). The difficult problem of maintaining the polders in the face of natural erosion, embankment breach, and insufficient government support is posing significant threats to the robustness of the SES.

Unforeseen ecological problems also emerged after the construction of the polders. Because the embankments disrupt the natural tidal flows in the rivers, heavy siltation can occur along outside walls of the polders (Agrawala et al. 2003). This altering of the sedimentation process can clog river channels and hamper the operation of sluice gates (arrow 7; FAO 1995). Thus, the polders in the region have increasingly experienced impaired drainage capacity and chronic water-logging issues (e.g., IFI Watch Bangladesh 2006). 
The polders are also experiencing land subsidence as well as sediment accretion. Historically, the SWBD floodplains have been sinking about $5 \mathrm{~mm}$ per year (Goodbred and Kuehl 2000, Hanebuth et al. 2013) while sediment is accumulating about $7 \mathrm{~mm}$ per year (Stanley and Hait 2000). Because the polders disrupt the natural sedimentation process, the lands enclosed by the embankments have lost up to 1.5 meters in elevation relative to the mean height of the surrounding bodies of water (Auerbach et al. 2015). Elevation loss of the lands inside the polders put additional stress on the embankments, making it more fragile to embankment breach and overtopping by high water levels (arrow 7; Saari and Rahman 2003). For example, around 2000 households were marooned when the embankment collapsed in polder 5, allegedly because of high tide pressures (The Daily Observer 2015). Embankment failures have become more common over the years, putting food security and human safety at greater risk.

In summary, the polders helped to improve the management of variance in shorter time scales. Normal flooding ended, e.g., daily tidal inundation, seasonal storm surge, etc. The impact intensity of tropical cyclones also declined. However, the system as a whole became fragile to a new set of challenges such as infrastructure maintenance issues, deferred government support, and ecological problems and their cascading effects. The system has also become more sensitive to cyclonic storms because of the increased economic activities inside the polders.

\section{Analysis III: Commercial shrimp farming}

The construction of the polders created an environment that is suitable for more intensive forms of aquaculture (arrows 4 and 5, Fig. 5). Hence, commercial shrimp farming (CSF) began to proliferate in the area from the late 1970s under the support of the government. The rationale was that CSF could further improve household income and food security by creating a more reliable complementary source of income. The government promoted CSF by leasing parts of the state-owned coastal lands to local farmers as well as nonlocal investors (Islam and Wahab 2005, Azad et al. 2009). Between 1975 and 2000, land areas for shrimp farming increased sevenfold, from $20 \mathrm{~K}$ hectares to $141 \mathrm{~K}$ hectares (BBS 1975, BBS 2002).

The expansion of CSF in the region brought substantial economic gains (arrow 1). During the period of 1975-2009, the country's revenue from shrimp export grew from US\$4M to \$437.4M (BBS 1975, BBS 2002, BFFEA 2008). The share of farmed fish and shrimp to the country's gross domestic product (GDP) increased to $3.32 \%$ by 2013 (BBS 2014), which makes CSF the second largest export sector after the garment industry (EPB 2017). Moreover, the CSF industry became an important employment sector at the national level, employing nearly 600,000 people in different subsectors of the industry (arrow 1; Karim 2003).

However, despite its benefits, CSF also brought with it a new set of challenges. First, new social problems emerged because of CSF. For example, politically influential shrimp farmers often expanded their shrimp ponds by systematically and wrongfully subjugating agricultural farmers to convert their agricultural lands. Paprocki and Cons (2014), as an illustration, reported that in polder 20 and 23, sluice gates were taken over and embankments were cut in places to inundate fertile lands, and thus poor agricultural farmers were evicted and their lands were usurped (see also Gain 1995, Ito 2002). Another example is the unemployment issue caused by CSF. Because CSF is about $90 \%$ less labor intensive than agriculture (Shiva 1995, Islam et al. 2002), the expansion of CSF in the SWBD caused as much as 49\% drop in employment at the local level over the period of 1975 to 1999 (Karim 2006).

Fig. 5. The robustness diagram of the social-ecological system (SES) with the polder and commercial shrimp farming (CSF). Line thickness indicates the relative importance of a given interaction. Despite the benefits of increased performance and robustness of food production, CSF can also make the SES fragile to several social issues (social conflicts, sensitivity to market volatility) and environmental problems (water pollution and soil quality degradation).

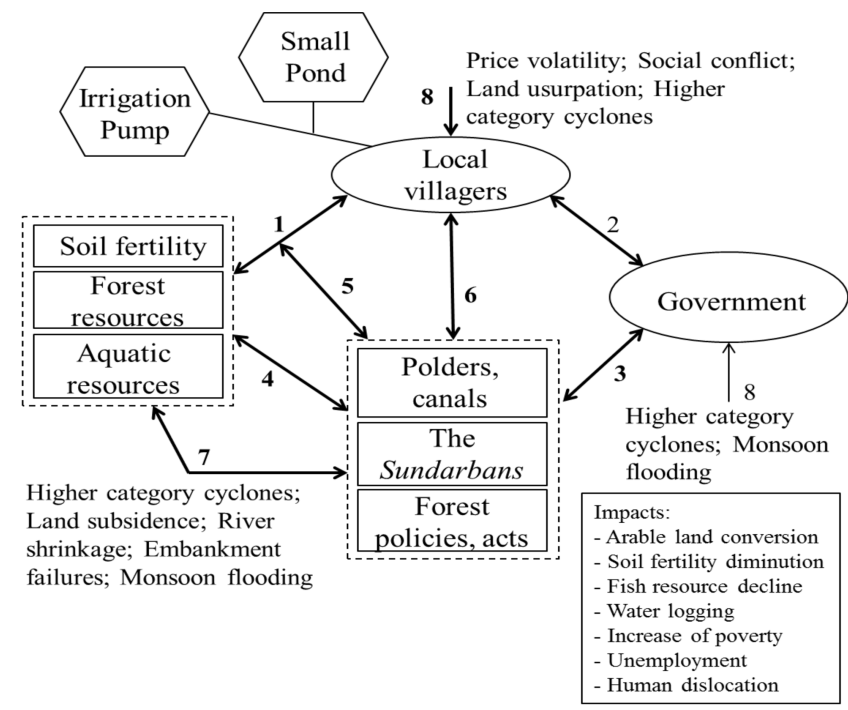

Second, CSF induced telecoupled fragilities of the local livelihood to the vagaries of the global shrimp market processes (arrow 8). For instance, Bangladesh's shrimp export to Europe increased by $3.9 \%$ in 2012 because of the influx of European buyers seeking for cheap supplies of shrimp. Projecting demand rise in the next few years, shrimp farmers in the SWBD intensified their productions. However, contrary to the expectation, Bangladesh's export to Europe decreased by $3.6 \%$ in 2014 because of economic recession in Europe (FAO 2015). Because the intensity of shrimp production largely depends on global market demand, rather than local, the European economic recession had a telecoupled effect on the shrimp production in Bangladesh. Our interviews with shrimp farmers suggested that several black tiger shrimp producers experienced substantial amount of losses because of the capital investments made under optimistic scenarios. This loss further cascaded through the entire shrimp industry affecting the larvae collectors, labors, and exporters.

Third, CSF induced several environmental problems such as water pollution and soil quality degradation. For example, as shrimp farmers transport saline water into and out of their ponds through canals, salts are often dispersed into nearby agricultural lands. This is a case of negative externality; neighboring agricultural farmers can suffer reduced crop output (Paul and 
Vog1 2011). Furthermore, intensive use of shrimp ponds impairs soil quality of the lands in the vicinity of the ponds for an extended period of time (Islam 2003) as well as increases the salinity of groundwater (Deb 1998, Chowdhury et al. 2006). A recent study by Soil Resource Development Institute of Bangladesh found that soil salinity expanded to 223,000 hectares of lands in inland polders between 1973 and 2009 (SRDI 2010). Saline water intrusion also exacerbates tensions between shrimp and agricultural farmers. For example, in 2009, shrimp farmers of polders 34 and 35 intentionally damaged their embankments (cut holes) to intake saline water because agricultural farmers took hold of the sluice gates to resist saline water intrusion (The Daily Star 2009).

Last, CSF disrupts the ecology of marine resources in the region. The recent agricultural statistics show that $70 \%$ of shrimp farmers practice semi-intensive methods, which requires higher inputs of postlarvae shrimps (BBS 2014). The need for these higher inputs is usually met by collecting shrimp fry from estuaries of the Ganges-Brahmaputra river delta (Shrimp News International 2014), which damages natural fish stocks (Sohel and Ullah 2012). In addition, polluted shrimp pond waters released from the polders contaminate surrounding water bodies and further cause damages to the natural fish stocks (Deb 1998, Neiland et al. 2001).

\section{DISCUSSION AND CONCLUSIONS}

The three-stage robustness analysis just discussed presents an interesting case of dynamic interplay between management efforts to reduce variance (or increase predictability) in socialecological system (SES) performance and unforeseen fragilities that emerge from such efforts. Earlier papers (Anderies 2015, Carpenter et al. 2015) on managing SES variances illuminate the robustness-fragility trade-offs (RFTOs) that may arise when short-term variances are suppressed. Different types of RFTOs and the consequences of managing variances are discussed in detail in these works. We have made concurring observations in our focal SES through the robustness analyses; this case study, thus in a way, supports the external validity of the works of Anderies (2015) and Carpenter et al. (2015).

Our focal SES in southwest Bangladesh (SWBD) is historically pounded by natural hazards because of its geographical location and ecological delicacies. The traditional management strategies were ineffective at reducing the short-term environmental variances and ensuring food security, which led the government to initiate a megainfrastructure project (Coastal Embankment Project) and foster livelihood diversification strategies (commercial shrimp farming). Both the CEP and CSF were successful to some extent in reducing the sensitivity of food production to natural hazards. However, as our robustness analyses suggest, these robustness-enhancing measures generated fragilities elsewhere. Reduction in variance of SES outputs to high-frequency events, e.g., daily tidal inundation, seasonal storm surge, etc., was accompanied by an increase in the variance to low-frequency or more gradually occurring events , e.g., infrastructure maintenance issues, land subsidence, higher intensity cyclones, etc. (see Fig. 6 for a conceptual illustration). Embankments safeguarded the polder interior from normal flooding and high-frequency storms, but it also led to increased population densities and intensified economic activities on the floodplains, making it more sensitive in the case of high intensity disturbances as well as gradual changes. Similarly, the diversification of income generation opportunities after the introduction of CSF initially resulted in the decreased variances and increased mean outputs, but it also brought with it a new set of fragilities in the longer run.

Fig. 6. A conceptual illustration of the variances in socialecological system outputs in response to hazards of different frequencies. Output variances in a system with the Coastal Embankment Project (CEP) and commercial shrimp farming (CSF) are less than those of the traditional system for a large range of storm frequencies because the introduction of embankments attenuates flooding during these storms. Overtopping during rare or low-frequency storms, however, can result in much larger output variances in a system with CEP and CSF because of the increased economic activities.

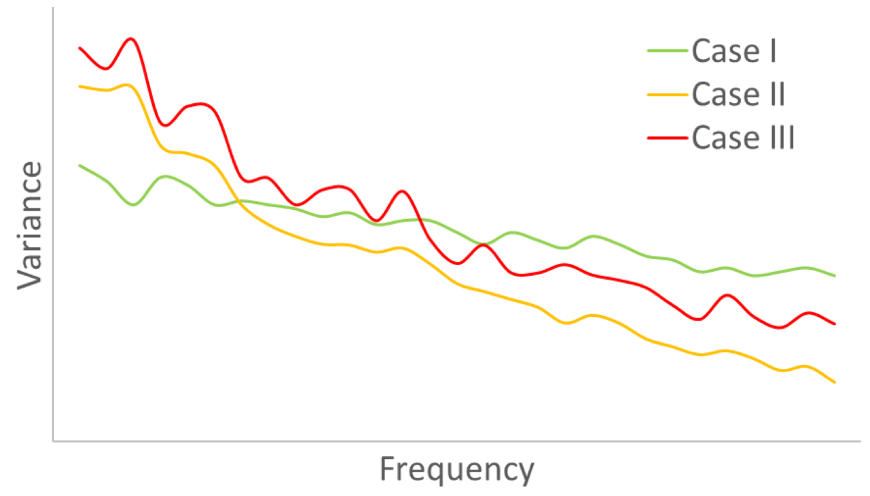

In the parlance of RFTO typology, CEP and CSF generated structural and network RFTOs, respectively. As mentioned earlier, embankment projects directly modified the resource system structure with the objectives of reducing high-frequency variances, and eventually resulted in the RFTO on different time scales and frequencies. CSF, on the other hand, generated network RFTO by creating a new parallel economic activity that is connected to a greater, outside system. Although, in overall, the introduction of CSF resulted in increased economic output, limited common land and water resources meant that the shrimp farming flourished at the expense of the agriculture sector. Because of its connection to the outside, the system also became vulnerable to external market fluctuations. A conceptual illustration of the RFTO effects of CEP and CSF is given in Figure 7. As shown, the traditional system is sensitive to even moderate natural disturbances, i.e., most natural disturbances result in loses of outputs (green bars in Fig. 7B). The CEP and CSF lessen the damage intensities of most of the low-intensity disturbances (Fig. 7B). However, higher levels of economic development in the polder after the introduction of CEP and CSF make the SES more sensitive to any overtopping occurring during the infrequent, extreme disturbances (yellow and red bars in Fig. 7B). Commensurate with the development levels, damages due to polder inundation and cyclonic storms are highest in the case of $\mathrm{CSF}$, which is additionally vulnerable to fluctuations in global 
Fig. 7. A conceptual illustration of linkages between external disturbances and resulting economic losses in the southwest Bangladesh social-ecological system (SES). (A) A time series of external disturbances, both natural disturbances and market volatility to which the SES is hypothetically exposed. (B) Time series of economic losses under different scenarios (traditional, Coastal Embankment Project [CEP], commercial shrimp farming [CSF]) that qualitatively captures the expected response of SES to the external disturbances shown in (A). Economic losses due to natural disturbances are smaller but more frequent in the case of the traditional system (green bars). CEP (golden bars) and CSF (red bars), on the other hand, are sensitive only to extreme natural disturbances but experience catastrophic losses when polders flood. Because of its increased connectivity to the global market, CSF (red crosses) is additionally sensitive to market volatility related disturbances as well.
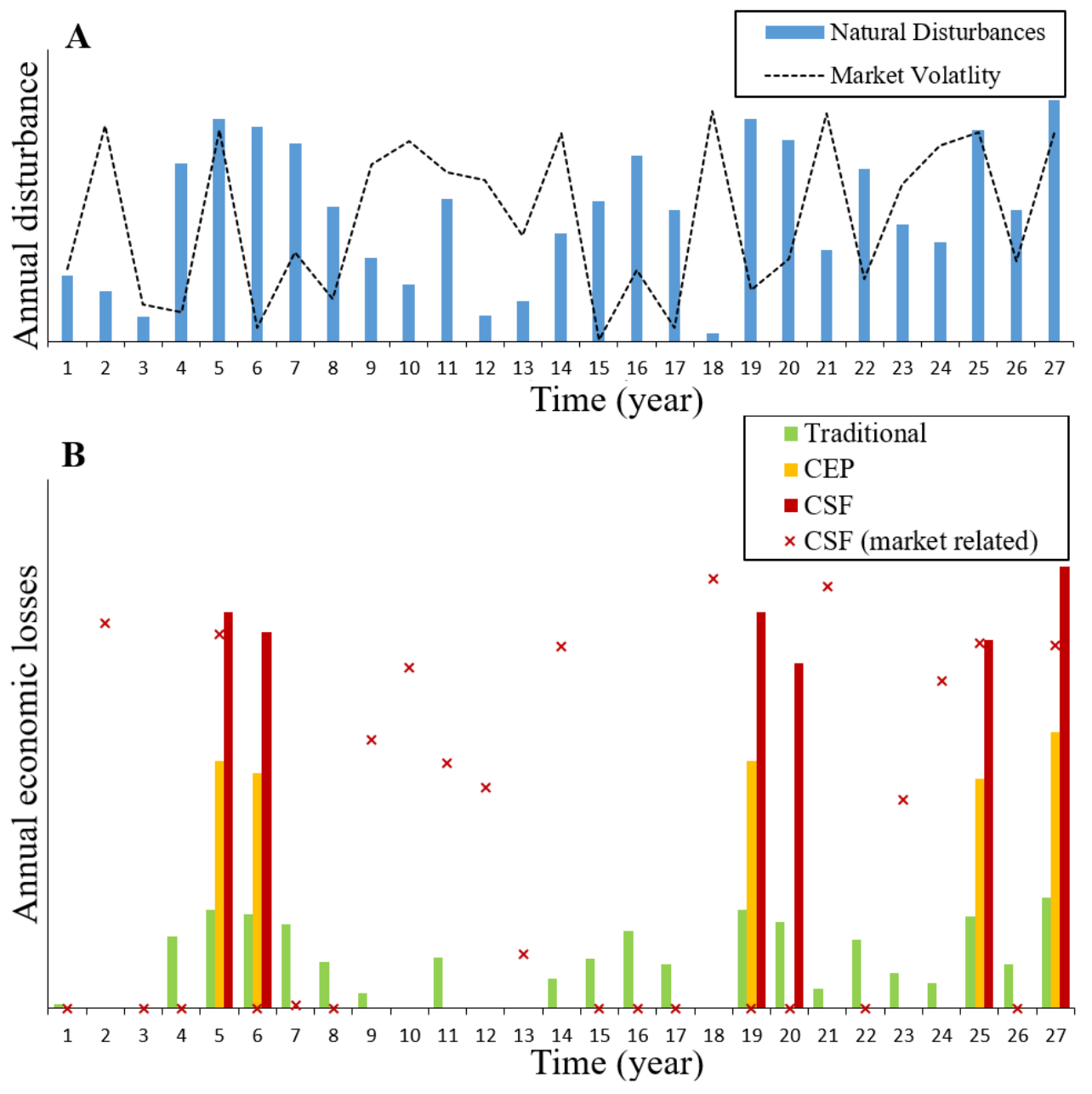

market. To illustrate, during the category-1 cyclone Aila shrimp farmers encountered $25 \%$ more damage than agricultural farmers (Abdullah et al. 2016).

Furthermore, many of these fragilities are usually hidden and structural measures (such as CEP) designed to suppress familiar disturbances result in overestimation of robustness among the coastal community. The structural measures successfully reduce the exposure to disturbances, yet it has been noted by numerous studies (e.g., Bohensky and Leitch 2014, Di Baldassare et al. 2015) that they eventually result in increased vulnerability because the reduced exposure causes the loss in societal memory of floods
(Alam and Collins 2010), thereby, encouraging increased development in the risk prone areas. Coined as the "levee effect" by Montz and Tobin (2008), it is an often-observed phenomenon across the globe, and is another example of RFTO between robustness in the short term and fragility in the long run. As seen in our case study, mild exposure to disturbances promotes coping and adaptive capacity, and prevents hazards from becoming catastrophes. We believe that a mixed, balanced strategy aimed at keeping short-term variances and adaptive capacity within reasonable limits is the most pragmatic way forward for SWBD and other risk prone regions (in particular, areas located along major rivers and coasts) of the world. 
The continuous endeavor by the government and nongovernment agencies to manage the RFTOs lead to disparate incremental efforts. The government, for instance, in association with WB initiated the Coastal Embankment Rehabilitation Project in 1987 and the Coastal Embankment Improvement Project in 2013 with the purpose of repairing and heightening the embankments. These initiatives assist the SES to maintain the robustness against short-term variances, but they cannot prevent the shifting of fragility in longer time scale, neither could they forestall the impact of higher intensity environmental variances substantially. Category-4 cyclone Sidr in 2007, as an illustrative example, fully destroyed $362 \mathrm{~km}$ of embankments, and damaged more than US\$1.7 billion worth of properties along the coast (GoB 2008). The government further developed an effective early warning and evacuation system through improvising radio and cellular networks, and constructing cyclone shelters across the entire coast. Although these efforts significantly reduced the human death toll (Paul 2009), they have yet to make the system robust because the empirical evidence reports that Bangladesh Meteorological Department cannot provide reliable forecasts beyond 12 hours, and considerable mistrust in warning messages exists among the residents of SWBD (Roy et al. 2015). The evacuation system is further impeded by religious superstitions and other socio-cultural reasons (Alam and Collins 2010, Garai 2017).

Looking into the future, coastal Bangladesh is likely to face more adversities because of global climate change (Dasgupta et al. 2010). The Intergovernmental Panel on Climate Change (IPCC) projects that by 2100 the coastal areas of Bangladesh will encounter at least $0.5 \mathrm{~m}$ rise in mean sea level resulting in a 15$20 \%$ rise in tidal surges (Church et al. 2013). Such trends of rising sea level can further cause overtopping of 26 polders in SWBD by 2050 (Dasgupta et al. 2014). The policy makers will need to combine conventional approaches and alternative management strategies to achieve SES robustness in both the short and longer term.

One alternative approach that we can consider is tidal river management (TRM), a traditional method that incorporates local knowledge, community participation, and engineering challenges (Tutu 2005, Islam and Kibria 2006, Shampa and Pramanik 2012, Khadim et al. 2013). TRM is a periodic process of allowing river water to inundate beel (geomorphic basin) for land accretion (or reclamation) by cutting and closing of polders (Islam 2006). This intentional allowance of inundation will help to restore natural sedimentation processes as well as keep the social memory of flood risk at high levels. Notably, some improvements have been achieved through the embankment rehabilitation projects, and establishment of flood forecasting stations and cyclone shelters. Yet, more investments will need to be made on the information sources of flood risk, such as improved weather forecasting and warning systems (Brammer 1990, Ahmad and Ahmed 2003) and detailed flood maps showing rare as well as frequent flood events (Wheater 2006). Further, community-based flood shelters need to be established in addition to increasing the facilities in existing cyclone shelters. Disaster recovery system needs to be made more efficient through enhancing institutional capacities and engaging local political and religious leaders. Additionally, the local people should be made aware of the physical deficiencies of the embankments, and thus not to be complacent to flood or cyclone risks. Active involvement of local people is also required along with governmental efforts in the maintenance of embankments (Afroz et al. 2016). Taken together, these alternative strategies will help to create more adaptive yet robust human-flood systems.

Responses to this article can be read online at: http://www.ecologyandsociety.org/issues/responses. $\mathrm{php/9186}$

\begin{abstract}
Acknowledgments:
Asif Ishtiaque thankfully acknowledges the assistance of Sheikh Mofizul Islam from Dhaka, and Mr. Akram from Satkhira during the field survey. The insightful contribution of Ms. Sharmin Afroz is thankfully acknowledged. David J. Yu and Nikhil Sangwan acknowledge financial support from Lyles School of Civil Engineering, Department of Political Science, and Center for the Environment at Purdue University.
\end{abstract}

\section{LITERATURE CITED}

Abdullah, A. N. M., K. K. Zander, B. Myers, N. Stacey, and S. T. Garnett. 2016. A short-term decrease in household income inequality in the Sundarbans, Bangladesh, following Cyclone Aila. Natural Hazards 83(2):1103-1123. http://dx.doi.org/10.1007/ s11069-016-2358-1

Afroz, S., R. Cramb, and C. Grunbuhel. 2016. Collective management of water resources in Coastal Bangladesh: formal and substantive approaches. Human Ecology 44(1):17-31. http:// dx.doi.org/10.1007/s10745-016-9809-X

Agrawala, S., T. Ota, A. U. Ahmed, J. Smith, and M. Van Aalst. 2003. Development and climate change in Bangladesh: focus on coastal flooding and the Sundarbans. Organisation for Economic Co-operation and Development, Paris, France.

Ahmad, Q. K., and A. U. Ahmed. 2003. Regional cooperation in flood management in the Ganges-Brahmaputra-Meghna region: Bangladesh perspective. Pages 181-198 in M. M. Q. Mirza, A. Dixit, and A. Nishat, editors. Flood problem and management in South Asia. Springer, Dordrecht, The Netherlands. http://dx.doi. org/10.1007/978-94-017-0137-2_9

Ahmed, N., H. Demaine, and J. F. Muir. 2008. Freshwater prawn farming in Bangladesh: history, present status and future prospects. Aquaculture Research 39(8):806-819. http://dx.doi. org/10.1111/j.1365-2109.2008.01931.x

Alam, E., and A. E. Collins. 2010. Cyclone disaster vulnerability and response experiences in coastal Bangladesh. Disasters 34 (4):931-954. http://dx.doi.org/10.1111/j.1467-7717.2010.01176.x

Alam, S. M. N., C. K. Lin, A. Yakupitiyage, H. Demaine, and M. J. Phillips. 2005. Compliance of Bangladesh shrimp culture with FAO code of conduct for responsible fisheries: a development challenge. Ocean \& Coastal Management 48(2): 177-188. http://dx. doi.org/10.1016/j.ocecoaman.2005.01.001

Ali, A. M. S. 2006. Rice to shrimp: land use/land cover changes and soil degradation in Southwestern Bangladesh. Land Use Policy 23(4):421-435. http://dx.doi.org/10.1016/j.landusepol.2005.02.001 
Anderies, J. M. 2006. Robustness, institutions, and large-scale change in social-ecological systems: the Hohokam of the Phoenix Basin. Journal of Institutional Economics 2(2):133-155. http://dx. doi.org/10.1017/s1744137406000312

Anderies, J. M. 2015. Managing variance: key policy challenges for the Anthropocene. Proceedings of the National Academy of Sciences 112(47):14402-14403. http://dx.doi.org/10.1073/pnas.1519071112

Anderies, J. M., C. Folke, B. Walker, and E. Ostrom. 2013. Aligning key concepts for global change policy: robustness, resilience, and sustainability. Ecology and Society 18(2):8. http:// dx.doi.org/10.5751/es-05178-180208

Anderies, J. M., M. A. Janssen, and E. Ostrom. 2004. A framework to analyze the robustness of social-ecological systems from an institutional perspective. Ecology and Society 9(1):18. http://dx. doi.org/10.5751/es-00610-090118

Arfanuzzaman, M., N. Mamnun, M. S. Islam, T. Dilshad, and M. A. Syed. 2016. Evaluation of adaptation practices in the agriculture sector of Bangladesh: an ecosystem based assessment. Climate 4(1):11. http://dx.doi.org/10.3390/cli4010011

Auerbach, L. W., S. L. Goodbred Jr, D. R. Mondal, C. A. Wilson, K. R. Ahmed, K. Roy, M. S. Steckler, C. Small, J. M. Gilligan, and B. A. Ackerly. 2015. Flood risk of natural and embanked landscapes on the Ganges-Brahmaputra tidal delta plain. Nature Climate Change 5:153-157. http://dx.doi.org/10.1038/nclimate2472

Azad, A. K., K. R. Jensen, and C. K. Lin. 2009. Coastal aquaculture development in Bangladesh: unsustainable and sustainable experiences. Environmental Management 44 (4):800-809. http://dx.doi.org/10.1007/s00267-009-9356-y

Aziz, A., and A. R. Paul. 2015. Bangladesh Sundarbans: present status of the environment and biota. Diversity 7(3):242-269. http://dx.doi.org/10.3390/d7030242

Bahn, O., M. Chesney, J. Gheyssens, R. Knutti, and A. C. Pana. 2015. Is there room for geoengineering in the optimal climate policy mix? Environmental Science \& Policy 48:67-76. http://dx. doi.org/10.1016/j.envsci.2014.12.014

Bandyopadhyay, D. 2000. Can Sundarbans be saved? Economics \& Political Weekly 35(45):3925-3928.

Bangladesh Bureau of Statistics (BBS). 1975. Statistical yearbook of Bangladesh. BBS, Dhaka, Bangladesh.

Bangladesh Bureau of Statistics (BBS). 2002. Statistical yearbook of Bangladesh. BBS, Dhaka, Bangladesh.

Bangladesh Bureau of Statistics (BBS). 2014. GDP 2013-14. BBS, Dhaka, Bangladesh.

Bangladesh Frozen Foods Exporters Association (BFFEA). 2008. Shrimp and fish news: news letter of Bangladesh Frozen Foods Exporters Association (BFFEA), April-June, 2008. BFFEA, Dhaka, Bangladesh.

Blasco, F. 1977. Outlines of ecology, botany and forestry of the mangals of the Indian subcontinent. Pages 241-260 in V. J. Chapman, editor. Wet coastal ecosystems, ecosystems of the world -1. Elsevier Scientific, Amsterdam, The Netherlands.

Bohensky, E. L., and A. M. Leitch. 2014. Framing the flood: a media analysis of themes of resilience in the 2011 Brisbane flood.
Regional Environmental Change 14(2):475-488. http://dx.doi. org/10.1007/s10113-013-0438-2

Brammer, H. 1990. Floods in Bangladesh: II. Flood mitigation and environmental aspects. Geographical Journal 156(2):158-165. http://dx.doi.org/10.2307/635323

Carlson, J. M., and J. Doyle. 2002. Complexity and robustness. Proceedings of the National Academy of Sciences 99(Suppl 1):2538-2545. http://dx.doi.org/10.1073/pnas.012582499

Carpenter, S. R., W. A. Brock, C. Folke, E. H. van Nes, and M. Scheffer. 2015. Allowing variance may enlarge the safe operating space for exploited ecosystems. Proceedings of the National Academy of Sciences 112(46):14384-14389. http://dx.doi. org/10.1073/pnas.1511804112

Choudhury, N. Y., A. Paul, and B. K. Paul. 2004. Impact of costal embankment on the flash flood in Bangladesh: a case study. Applied Geography 24(3):241-258. http://dx.doi.org/10.1016/j. apgeog.2004.04.001

Chowdhury, M. A., G. P. Shivakoti, and M. Salequzzaman. 2006. A conceptual framework for the sustainability assessment procedures of the shrimp aquaculture industry in coastal Bangladesh. International Journal of Agricultural Resources, Governance and Ecology 5(2-3):162-184. http://dx.doi.org/10.1504/ ijarge.2006.009162

Church, J. A., P. U. Clark, A. Cazenave, J. M. Gregory, S. Jevrejeva, A. Levermann, M. A. Merrifield, G. A. Milne, R. S. Nerem, P. D. Nunn, A. J. Payne, W. T. Pfeffer, D. Stammer and A. S. Unnikrishnan, 2013. Sea level change. Pages 1137-1216 in T. F. Stocker, D. Qin, G.-K. Plattner, M. Tignor, S. K. Allen, J. Boschung, A. Nauels, Y. Xia, V. Bex, and P. M. Midgley, editors. Climate Change 2013: The Physical Science Basis. Contribution of Working Group I to the Fifth Assessment Report of the Intergovernmental Panel on Climate Change Cambridge University Press, Cambridge, UK.

Cifdaloz, O., A. Regmi, J. M. Anderies, and A. A. Rodriguez. 2010. Robustness, vulnerability, and adaptive capacity in smallscale social-ecological systems: the Pumpa Irrigation System in Nepal. Ecology and Society 15(3):39. http://dx.doi.org/10.5751/ es-03462-150339

Csete, M. E., and J. C. Doyle. 2002. Reverse engineering of biological complexity. Science 295(5560):1664-1669. http://dx. doi.org/10.1126/science.1069981

Curtis, S. J. 1933. Working plan for the forests of the Sundarbans division (April 1931 to March 1951). Bengal Government Press, Calcutta, India.

Das, S., and N. A. Siddiqui. 1985. The mangroves and mangrove forests of Bangladesh. Mangrove Silivculture Division Bulletin No. 2, BFRI and UNDP/FAO Project, BGD/79/017. Chittagong, Bangladesh.

Dasgupta, S., M. Huq, Z. H, Khan, M. M. Z. Ahmed, N. Mukherjee, M. F. Khan, and K. D. Pandey. 2010. Vulnerability of Bangladesh to cyclones in a changing climate: potential damages and adaptation cost. World Bank Policy Research Working Paper Series. World Bank, Washington, D.C., USA. 
Dasgupta, S., M. Huq, Z. H. Khan, M. M. Z. Ahmed, N. Mukherjee, M. F. Khan, and K. Pandey. 2014. Cyclones in a changing climate: the case of Bangladesh. Climate and Development 6(2):96-110. http://dx.doi.org/10.1080/17565529.2013.868335

Daupras, F., J. M. Antoine, S. Becerra, and A. Peltier. 2015. Analysis of the robustness of the French flood warning system: a study based on the 2009 flood of the Garonne River. Natural Hazards 75(1):215-241. http://dx.doi.org/10.1007/s11069-014-1318$\underline{\mathrm{x}}$

Deb, A. K. 1998. Fake blue revolution: environmental and socioeconomic impacts of shrimp culture in the coastal areas of Bangladesh. Ocean \& Coastal Management 41(1):63-88. http:// dx.doi.org/10.1016/s0964-5691(98)00074-x

Dewan, C., A. Mukherji, and M.-C. Buisson. 2015. Evolution of water management in coastal Bangladesh: from temporary earthen embankments to depoliticized community-managed polders. Water International 40(3):401-416. http://dx.doi. org/10.1080/02508060.2015.1025196

Di Baldassarre, G., A. Viglione, G. Carr, L. Kuil, K. Yan, L. Brandimarte, and G. Blöschl. 2015. Debates-perspectives on socio-hydrology: capturing feedbacks between physical and social processes. Water Resources Research 51(6): 4770-4781. http://dx. doi.org/10.1002/2014wr016416

Export Promotion Bureau (EPB). 2017. Product wise export for the month of July 2016-17. EPB, Ministry of Commerce, Dhaka, Bangladesh. [online] URL: http://epb.portal.gov.bd/site/files/51916ae6a9a3-462e-a6bd-9ef074d835af $/ \%$ E0 $\%$ A $6 \%$ AA $\%$ E0 $\%$ A $6 \%$ B $0 \%$ E0 $\%$ A6\%BF $\% \mathrm{E} 0 \% \mathrm{~A} 6 \% \mathrm{~B} 8 \% \mathrm{E} 0 \% \mathrm{~A} 6 \% 82 \% \mathrm{E} 0 \% \mathrm{~A} 6 \% 96 \% \mathrm{E} 0 \% \mathrm{~A} 7 \% 8 \mathrm{D} \%$ $\mathrm{E} 0 \% \mathrm{~A} 6 \% \mathrm{AF} \% \mathrm{E} 0 \% \mathrm{~A} 6 \% \mathrm{BE} \% \mathrm{E} 0 \% \mathrm{~A} 6 \% \mathrm{~A} 8-\% \mathrm{E} 0 \% \mathrm{~A} 6 \% \mathrm{~A} 1 \% \mathrm{E} 0 \%$ A $6 \% \mathrm{BE} \% \mathrm{E} 0 \% \mathrm{~A} 6 \% 9 \mathrm{~F} \% \mathrm{E} 0 \% \mathrm{~A} 6 \% \mathrm{BE}-\% \mathrm{E} 0 \% \mathrm{~A} 7 \% \mathrm{~A} 8 \% \mathrm{E} 0 \% \mathrm{~A} 7 \%$ A $6 \%$ E $0 \% \mathrm{~A} 7 \% \mathrm{~A} 7 \% \mathrm{E} 0 \% \mathrm{~A} 7 \% \mathrm{AC}-\% \mathrm{E} 0 \% \mathrm{~A} 7 \% \mathrm{~A} 8 \% \mathrm{E} 0 \% \mathrm{~A} 7 \% \mathrm{~A} 6 \%$ E0 $\% \mathrm{~A} 7 \% \mathrm{~A} 7 \% \mathrm{E} 0 \% \mathrm{~A} 7 \% \mathrm{AD}$

Food and Agriculture Organization of the United Nations (FAO). 1995. Report on national workshop on fisheries resources development and management in Bangladesh. FAO, Rome, Italy.

Food and Agriculture Organization of the United Nations (FAO). 2015. GLOBEFISH - analysis and information on world fish trade. FAO, Rome, Italy. [online] URL: http://www.fao.org/in-action/ globefish/market-reports/resource-detail/en/c/337857/

Gain, A. K., and C. Giupponi. 2014. Impact of the Farakka Dam on thresholds of the hydrologic flow regime in the Lower Ganges River Basin (Bangladesh). Water 6(8):2501-2518. http://dx.doi. org/10.3390/w6082501

Gain, P. 1995. Bangladesh: attack of the shrimps. Third World Resurgence 59:18-19.

Garai, J. 2017. Qualitative analysis of coping strategies of cyclone disaster in coastal area of Bangladesh. Natural Hazards 85 (1):425-435. http://dx.doi.org/10.1007/s11069-016-2574-8

Goodbred, S. L., and S. A. Kuehl. 2000. The significance of large sediment supply, active tectonism, and eustasy on margin sequence development: Late Quaternary stratigraphy and evolution of the Ganges-Brahmaputra delta. Sedimentary Geology 133(3-4):227-248. http://dx.doi.org/10.1016/s0037-0738 (00)00041-5
Gopal, B., and M. Chauhan. 2006. Biodiversity and its conservation in the Sundarban Mangrove Ecosystem. Aquatic Sciences 68(3):338-354. http://dx.doi.org/10.1007/s00027-006-0868-8

Government of the People's Republic of Bangladesh (GoB). 2008. Cyclone Sidr in Bangladesh: damage, loss, and needs assessment for disaster recovery and reconstruction. GoB, Dhaka, Bangladesh. [online] URL: http://reliefweb.int/sites/reliefweb.int/ files/resources/F2FDFF067EF49C8DC12574DC00455142-Full Report. pdf

Hanebuth, T. J. J., H. R. Kudrass, J. Linstädter, B. Islam, and A. M. Zander. 2013. Rapid coastal subsidence in the central GangesBrahmaputra Delta (Bangladesh) since the 17th century deduced from submerged salt-producing kilns. Geology 41(9):987-990. http://dx.doi.org/10.1130/G34646.1

Hossain, M. N. 2015. Analysis of human vulnerability to cyclones and storm surges based on influencing physical and socioeconomic factors: evidences from coastal Bangladesh. International Journal of Disaster Risk Reduction 13:66-75. http:// dx.doi.org/10.1016/j.ijdrr.2015.04.003

Huq, N., J. Hugé, E. Boon, and A. Gain. 2015. Climate change impacts in agricultural communities in rural areas of coastal Bangladesh: a tale of many stories. Sustainability 7(7):8437-8460. http://dx.doi.org/10.3390/su7078437

IFI Watch Bangladesh. 2006. The development disaster: waterlogging in the southwest region of Bangladesh. The Innovators/Unnayan Annyashan, Dhaka, Bangladesh.

Islam, M. R. 2006. Managing diverse land uses in coastal Bangladesh: institutional approaches. Page 237-248 in C. T. Hoanh, T. P. Tuong, J. W. Gowing, and B. Hardy, editors. Environment and livelihoods in tropical coastal zones: managing agriculture-fishery-aquaculture conflicts. CABI, Wallingford, UK. http://dx.doi.org/10.1079/9781845931070.0237

Islam, M. S. 2003. Perspectives of the coastal and marine fisheries of the Bay of Bengal, Bangladesh. Ocean \& Coastal Management 46(8):763-796. http://dx.doi.org/10.1016/s0964-5691(03)00064-4

Islam, M. S., and M. A. Wahab. 2005. A review on the present status and management of mangrove wetland habitat resources in Bangladesh with emphasis on mangrove fisheries and aquaculture. Pages 165-190 in H. Segers and K. Martens, editors. Aquatic biodiversity II: the diversity of aquatic ecosystems. Springer, Dordrecht, The Netherlands. http://dx.doi. org/10.1007/1-4020-4111-X_19

Islam, M. S., M. A. Wahab, and A. A. Miah. 2002. Socioeconomic and environmental impacts of alternate shrimp-crop farming in Bangladesh. Bangladesh Journal of Agricultural Economics 25 (1):63-76.

Islam, S., and Z. Kibria. 2006. Unraveling KJDRP: ADB financed project of mass destruction in southwest coastal region of Bangladesh. Uttaran, Satkhira, Bangladesh.

Ito, S. 2002. From rice to prawns: economic transformation and agrarian structure in rural Bangladesh. Journal of Peasant Studies 29(2):47-70. http://dx.doi.org/10.1080/714003949

Karim, M. R. 2003. Present status and strategies for future development of shrimp farming in Bangladesh. Pages 1-8 in M. 
A. Wahab, editor. Environmental and socioeconomic impact of shrimp farming in Bangladesh. Technical Proceeding BAUNORAD Workshop, 5 March, 2002. BRAC Center, Dhaka, Bangladesh.

Karim, M. R. 2006. Brackish-water shrimp cultivation threatens permanent damage to coastal agriculture in Bangladesh. Pages 61-71 in C. T. Hoanh, T. P. Tuong, J. W. Gowing, and B. Hardy, editors. Environment and livelihoods in tropical coastal zones: managing agriculture-fishery-aquaculture conflicts. CABI, Wallingford, UK. http://dx.doi.org/10.1079/9781845931070.0061

Khadim, F. K., K. K. Kar, P. K. Halder, M. A. Rahman, and A. M. Morshed. 2013. Integrated water resources management (IWRM) impacts in south west coastal zone of Bangladesh and fact-finding on tidal river management (TRM). Journal of Water Resource and Protection 5(10):953. http://dx.doi.org/10.4236/ jwarp.2013.510098

Khalil, G. M. 1992. Cyclones and storm surges in Bangladesh: some mitigative measures. Natural Hazards 6(1):11-24. http://dx. doi.org/10.1007/bf00162096

Krupa, M. B., F. S. Chapin III, and A. L. Lovecraft. 2014. Robustness or resilience? Managing the intersection of ecology and engineering in an urban Alaskan fishery. Ecology and Society 19(2):17. http://dx.doi.org/10.5751/es-06274-190217

Lázár, A. N., D. Clarke, H. Adams, A. R. Akanda, S. Szabo, R. J. Nicholls, Z. Matthews, D. Begum, A. F. M. Saleh, M. A. Abedin, A. Payo, P. K. Streatfield, C. Hutton, M. S. Mondal, and A. Z. M. Moslehuddin. 2015. Agricultural livelihoods in coastal Bangladesh under climate and environmental change - a model framework. Environmental Science. Processes \& Impacts 17 (6):1018-1031. http://dx.doi.org/10.1039/c4em00600c

Lemos, M. C., Y. J. Lo, D. R. Nelson, H. Eakin, and A. M. BedranMartins. 2016. Linking development to climate adaptation: leveraging generic and specific capacities to reduce vulnerability to drought in NE Brazil. Global Environmental Change 39:170-179. http://dx.doi.org/10.1016/j.gloenvcha.2016.05.001

Mens, M. J. P., F. Klijn, K. M. de Bruijn, and E. van Beek. 2011. The meaning of system robustness for flood risk management. Environmental Science \& Policy 14(8):1121-1131. http://dx.doi. org/10.1016/j.envsci.2011.08.003

Montz, B. E., and G. A. Tobin. 2008. Livin' large with levees: lessons learned and lost. Natural Hazards Review 9(3):150-157. http://dx.doi.org/10.1061/(asce)1527-6988(2008)9:3(150)

Murty, T. S., and M. I. El-Sabh. 1992. Mitigating the effects of storm surges generated by tropical cyclones: a proposal. Natural Hazards 6(3):251-273. http://dx.doi.org/10.1007/bf00129511

Murty, T. S., R. A. Flather, and R. F. Henry. 1986. The storm surge problem in the bay of Bengal. Progress in Oceanography 16 (4):195-233. http://dx.doi.org/10.1016/0079-6611(86)90039-X

Naskar, K. R., and R. N. Mandal. 1999. Ecology and biodiversity of Indian mangrove. Volumes 1 and 2. Daya Publishing House, New Delhi, India.

Neiland, A. E., N. Soley, J. B. Varley, and D. J. Whitmarsh. 2001. Shrimp aquaculture: economic perspectives for policy development. Marine Policy 25(4):265-279. http://dx.doi. org/10.1016/s0308-597x(01)00017-3

Paprocki, K., and J. Cons. 2014. Life in a shrimp zone: aqua- and other cultures of Bangladesh's coastal landscape. Journal of Peasant Studies 41(6):1109-1130. http://dx.doi.org/10.1080/0306$\underline{6150.2014 .937709}$

Paul, B. G., and C. R. Vogl. 2011. Impacts of shrimp farming in Bangladesh: challenges and alternatives. Ocean \& Coastal Management 54(3):201-211. http://dx.doi.org/10.1016/j. ocecoaman.2010.12.001

Paul, B. K. 2009. Why relatively fewer people died? The case of Bangladesh's Cyclone Sidr. Natural Hazards 50(2):289-304. http://dx.doi.org/10.1007/s11069-008-9340-5

Pérez, I., M. A. Janssen, A. Tenza, A. Giménez, A. Pedreño, and M. Giménez. 2011. Resource intruders and robustness of socialecological systems: an irrigation system of Southeast Spain, a case study. International Journal of the Commons 5(2):410-432. http://dx.doi.org/10.18352/ijc. 278

Pokrant, B. 2006. The organisation and development of coastal brackish water export oriented shrimp production in Bangladesh: a critical review of the literature. Pages 299-320 in A. A. Rahman, A. H. G. Quddus, B. Pokrant, and M. Liaquat, editors. Shrimp farming and industry: sustainability, trade and livelihoods. Bangladesh Centre of Advanced Studies, The University Press Limited, Dhaka, Bangladesh.

Rahman, M. M., M. Q. Hassan, M. S. Islam, and S. Z. K. M. Shamsad. 2000. Environmental impact assessment on water quality deterioration caused by the decreased Ganges outflow and saline water intrusion in south-western Bangladesh. Environmental Geology 40(1-2):31-40. http://dx.doi.org/10.1007/ s002540000152

Rahman, M. M., and M. M. Hossain. 2009. Production and export of shrimp of Bangladesh: problems and prospects. Progressive Agriculture 20(1-2):163-171. http://dx.doi.org/10.3329/ pa.v20i1-2.16868

Roy, C., S. K. Sarkar, J. Åberg, and R. Kovordanyi. 2015. The current cyclone early warning system in Bangladesh: providers' and receivers' views. International Journal of Disaster Risk Reduction 12:285-299. http://dx.doi.org/10.1016/j.ijdrr.2015.02.004

Saari, M., and S. Rahman. 2003. Development of the coastal embankment system in Bangladesh. Pages 115-125 in C. Goudas, G. Katsiaris, V. May, and T. Karambas, editors. Soft shore protection: an environmental innovation in coastal engineering. Springer, Dordrecht, The Netherlands. http://dx.doi. org/10.1007/978-94-010-0135-9 9

Shampa, M., and M. Paramanik, 2012. Tidal river management (TRM) for selected coastal area of Bangladesh to mitigate drainage congestion. International Journal of scientific and Technology Research 1:1-6.

Shiva, V. 1995. The damaging social and environmental effects of aquaculture. Third World Resurgence 59(2):2-24.

Shrimp News International. 2014. Bangladesh shrimp hatcheries. 10 January. [online] URL: http://www.shrimpnews.com/ FreeReportsFolder/NewsReportsFolder/BangladeshShrimpHatcheries. $\underline{\mathrm{html}}$ 
Sohel, M. S. I., and M. H. Ullah. 2012. Ecohydrology: a framework for overcoming the environmental impacts of shrimp aquaculture on the coastal zone of Bangladesh. Ocean \& Coastal Management 63:67-78. http://dx.doi.org/10.1016/j.

ocecoaman.2012.03.014

Soil Resource Development Institute (SRDI). 2010. Saline soils of Bangladesh. Ministry of Agriculture, Government of Bangladesh, Dhaka, Bangladesh.

Stanley, D. J., and A. K. Hait. 2000. Holocene depositional patterns, neotectonics and Sundarban mangroves in the western Ganges-Brahmaputra delta. Journal of Coastal Research 16 (1):26-39.

Swapan, M. S. H., and M. Gavin. 2011. A desert in the delta: participatory assessment of changing livelihoods induced by commercial shrimp farming in Southwest Bangladesh. Ocean \& Coastal Management 54(1):45-54. http://dx.doi.org/10.1016/j. ocecoaman.2010.10.011

Temmerman, S., and M. L. Kirwan. 2015. Building land with a rising sea. Science 349(6248):588-589. http://dx.doi.org/10.1126/ science.aac8312

The Daily Observer. 2015. 15 Satkhira villages flooded for embankment collapse. 25 March. [online] URL: http://www. observerbd.com/2015/03/25/79820.php

The Daily Star. 2009. Farmers resist saline water based shrimp farming. 11 May. [online] URL: http://archive.thedailystar.net/ newDesign/news-details.php?nid=87724

Tutu, A. 2005. River management in Bangladesh: a people's initiative to solve water-logging. Participatory Learning and Action 51:117-123.

Van Schendel, W. 2009. A history of Bangladesh. Cambridge University Press, Cambridge, UK. http://dx.doi.org/10.1017/ cbo9780511997419

Wheater, H. S. 2006. Flood hazard and management: a UK perspective. Philosophical Transactions: Mathematical, Physical and Engineering Sciences 364(1845):2135-2145. http://dx.doi. org/10.1098/rsta.2006.1817 